\title{
LIENS SECURING REIMBURSEMENT FOR COUNTY HOSPITAL CARE: 1963 DEVELOPMENTS
}

California law requires counties to provide general relief in the form of funds and services to county residents who are not supported by private or other public sources. ${ }^{1}$ The availability of general relief, therefore, provides the county resident with a residuum of resources, sliould all other sources fail. County general relief may be contrasted with the other major California public assistance programs, which make available funds to meet only certain "categories" of needs in the community; namely, the needs of the aged, the blind, the disabled, and children. ${ }^{2}$ These programs, which will be referred to as tlie "categorical aid" programs because of their particularized application, ${ }^{3}$ are AFDC (Aid to Families With Dependent Children), ${ }^{4}$ OAS (Old Age Security), ${ }^{5}$ AB (Aid to the

1 CAL. Welfare \& INST'NS CODE $\$ 2500$ provides: "Every county and every city and county shall relieve and support all incounpetent, poor, indigent persons and those incapacitated by age, disease, or accident, lawfully resident therein, when such persons are not supported and relieved by their relatives or friends, or by their own means, or by State hospitals or other State or private institutions." The provisions of $\$ 2500$ are mandatory. County of Los Angeles v. Frisbic, 19 Cal. 2d 634, 122 P.2d 526 (1942); County of Los Angeles v. Payne, 8 Cal. 2d 563, 66 P.2d 658 (1937); City and County of San Francisco v. Collins, 216 Cal. 187, 13 P.2d 912 (1932).

Section 2500 probably applies to charter counties as well as general law counties, for the statute seems well within the legislature's constitutional power to prescrihe the duties of the boards of supervisors and welfare administrators of chartered counties. CAL. CoNST. art. XI, $\$ 7 / 2$ (4). See City and County of San Francisco v. Collins, supra (with respect to the 1931 Pauper Act, CaL. Gen. Laws ANv. act 5814 (Deering 1931), the predecessor of \$2500, San Francisco functions as a county and, as such, is required by the act to provide rehef, notwith. standing contrary charter provisions).

The Collins case also indicates that provision of general rehef medical care is probably a matter of statewide concern for which comprehensive state policies could be established. Failure of the state to contribute state funds and exercise detailed control over general rehef thereforc seems not to stem from any objection that the use of state funds for general relief would violate the constitutional prohibition of spending state moneys for local purposes. See CaL. Const. art. XI, $\S 12$. Rather, this failure seems to reflect the traditional American position that responsibility for the care of the indigent is upon local entities. See RIESENFELd \& MAXWELL, MODERN SocraI LegisLation 685-822 (1950).

2 The distinction between the categorical aid programs and county general relief is generally recognized throughout the Code. See, e.g., Car. Werfare \& INST'Ns Code $\$ 427$ (express recognition of the distinction).

3 CAL. WeLfare \& INST'NS CODE $§ 200$ refers to the various puble assistance programs as "public social services." The generic reference includes both the "categorical aid" and the "general rehef" programs. While the code specifically alludes neither to "categorical aid" nor to "general rehef" as types of "public social services," the teruns seem popular among welfare officials and, the writer believes, serve to facilitate the following discussion.

${ }^{4}$ CAL. Welfare \& InST'NS Code $\$ \$ 1500-79$. The program, formerly entitled ANC (Aid to Needy Children) was renamed AFDC in 1963. Cal. Stat. ch. 2096, \& 5 (1963). AFDC provides assistance to families with children under eighteen years of age deprived of parental support because of specifically enumerated causes including death, physical or mental incapacity, desertion, and unemployment, and to children under eighteen who are without families and need support. Where a family unit still exists, the object is to preserve it; where the child is separated from his natural parents, for example where he has been relinquished for purposes of adoption, the object is to provide a substitute both by providing subsistance to the child and by encouraging placement in foster homes.

5 CAL. WeLtare \& Inst'ns CODE $\$ \$ 2000-2230$. OAS provides assistance to persons age 65 and over who are not self-supporting and do not receive adequate support from a spouse or child. 
Blind), ${ }^{6}$ APSB (Aid to the Partially Self-supporting Blind), ${ }^{7}$ ATD (Aid to the Totally Disabled), ${ }^{8}$ PAMC (Public Assistance Medical Care), ${ }^{9}$ and MAA (Medical Aid to the Aged). ${ }^{10}$

Three features, in addition to the residual nature of county general relief, distinguish it from categorical aid. First, general relief is financed solely by county moneys while the state and federal governments participate with the counties in the categorical aid programs. ${ }^{11}$ Second, each county normally furnishes general rehef only to its own residents, but county residence is not required for categorical aid..$^{12}$ Third, the eligibility requirements, type and amount of rehef, and the conditions to be attached to indigent relief have been left largely within the discretion of the counties; administrative decisions relating to categorical aid generally are made by the State Department of Social Welfare. ${ }^{13}$

Although these features manifest an empliasis on local control by the counties of general relief, the state legislature has frequently interjected specific

${ }^{6}$ CAL. WELFARE \& INST'NS CODE $\$ \$ 3000-93$. AB provides aid to persons who are not selfsupporting because of loss or impairment of eyesight. The program includes provisions designed to encourage physical rehabilitation, plans for self-support, and other efforts to regain selfsufficiency.

$\tau$ CAL. WELFARE \& INST'NS CODE $\$ \$ 3400-73$. APSB provides that certain persons, who are only partially self-supporting because of loss or impairment of eyesight, may retain substantial income and resources and still receive aid. The program is specifically designed for those who manifest the ability and desire eventually to become entirely self-supporting.

${ }^{8}$ CAL. WeLFARE \& INST'NS Code $\$ \$ 4000-4192$. ATD provides assistance to persons who are not self-supporting because of permanent physical or inental disability. The prograin includes provisions designed to encourage self-sufficiency, especially through vocational rehabilitation,

${ }^{9}$ CAL. WELFARE \& INST'NS CODE $\$ \$ 4500-4605$. PAMC provides funds for a wide range of out-patient medical services to recipients of AFDC, OAS, AB, APSB, and ATD who cannot finance the services themselves. For a thorough analysis of the provisions of the PAMC law see ten Broek, California's New Medical Care Law and Program, 46 CALIF. L. Rev. 558 (1958).

${ }^{10}$ CaI. Wetfare \& INST'NS CoDE $\$ \$ 4700-56$. MAA provides funds for long-term medical services to persons age 65 years and over who are not recipients of OAS and cannot finance the services themselves.

${ }^{11}$ Both state and federal governments participate with the county to finance AFDC, OAS, AB, ATD, MAA, and PAMC. See, e.g., 49 Stat. 620 (1935), 42 U.S.C. $\$ \$ 301-1385$; CAL. WELFARE \& INST'NS CODE $\$ \S 4750-53$ (relating to MAA). Only the state participates with the county to finance APSB. See CAI. WELFARE \& INST'NS CODE $\$ 3420$.

12 CAI. WELFARE \& INST'NS CODE $\$ \$ 2550-56$ establish the general rule that recipients of general rehief must be residents both of the state and of the county wherein application is inade. This rule applies to county hospital care. CAL. HealtH \& SAfETy Code $\$ 1446 ; 26$ OPS. CAL. ATT'Y GEN. 42 (1955). The rule includes the duty of every county to pay for the expense of treatinent of its indigent residents furnished by another county's county hospital. CAL. HEALTE \& SAFETY CODE $\$ 1475$. Disputes between different counties with respect to their respective responsibilities under this section are decided by the State Department of Social Welfare. CaL. Welfare \& INST'NS CODE \$2504. There are some exceptions to the rule. E.g., Car. Health \& SAFETY CODE $\$ 1447$ (counties responsible for administering certain categorical aid programs are responsible for furnishing county hospital care to recipients of such aid, notwithstanding the normal residence requirements).

${ }^{13}$ See CaI. Welfare \& Inst'ns CoDe $\$ 200$. In contrast with its role in categorical aid programs, the State Department of Social Welfare does not possess general administrative control over county relief policies. County of Los Angeles v. Dept. Social Welfare, $41 \mathrm{Cal}$. 2d 455, 260 P.2d 41 (1953), criticized, 41 CaLrF. L. REv. 499 (1953) ; Patten v. San Diego County, 106 Cal. App. 2d 467, 235 P.2d 217 (1951). Mlustrative, as well as germane to a discussion of county lien policies, is CAL. WELFARE \& INST'NS CODE $\$ 2600$, which provides: "The board of supervisors of any county may establish its own policies with reference to the amount of property, if any, a person shall be permitted to have while receiving public assistance, to the end that so far as it is possible an applicant for public relief shall be required to apply his own property to his support." 
expressions of statewide policy which all counties must follow. ${ }^{14}$ A series of 1963 amendments to the Welfare and Institutions Code limiting the authority of counties to impose liens securing reimbursement for the cost of county hospital care constitute such a policy expression and provide the basis for this Comment.

This Comment will consider first the hability of patients and their relatives to reimburse for county hospital care and the role played by liens in county collection policies. The discussion will then focus upon the pre-1963 statutory rules defining county authority to impose and enforce reimbursement liens, the changes made by the 1963 amendments, and a special problem of retroactivity posed by the amendments. Since the discussion will relate primarily to problems of county hospital care, it may be helpful to describe, as a preliminary matter, the general context in which these problems normally arise.

Medical care for indigent persons is required by law to be included in county general relief programs. ${ }^{15}$ Counties are authorized to provide a rather wide range of services in discharging the duty, ${ }^{16}$ and most counties provide the bulk of these services through county hospitals. ${ }^{17}$ Althougl county hospitals traditionally function as parts of the county programs of general relief for indigents, in fact county hospital care is furnished, in many cases, to persons who have at least a limited ability to reimburse the county for the cost of their care. ${ }^{18}$ Collection for county hospital care from these persons constitutes an integral part of the administration of most county hospitals. ${ }^{13}$

Counties, perhaps because of the difficulties involved in making collections, ${ }^{20}$ often have used property liens as aids for collection. Liens created by written conveyances from the patient or his relative to the county have been frequently

14 Apposite is CaL. WeLFARE \& INST'NS CODE $\$ 2500$, which imposes upon all counties the duty to provide general relief.

15 Madison v. City and County of San Francisco, 106 Cal, App.2d 232, 234 P.2d 995 (1951). This case reads CaL. WeLfare \& INST'NS CODE $\$ 2500$ and the predecessor of CaL. Health \& Safety Code $\$ 1445$ (Cal. Welfare \& Inst'Ns Code $\$ 200$ ) together to result in a duty of the county to provide medical care to indigents. Sec also 33 Ops. CAL. ATT'Y GEN. 158 (1959).

16 See Cal. Health \& Safety Code $\$ 1445$. Los Angeles, for example, provides inpatient and outpatient medical care, home nursing, nursing homes, some dental services, and eycglasses, hearing aids, and other prosthetic appliances. GreENFIELd, MEdical CARE FOR WeLfare Rectpients-State Programs 25-26 (University of California, 1957).

17 Id. at 25. CAL. HeALTH \& SAFETY CODE $\$ 1441$ provides the authority for counties to establish and maintain county lospitals. Threc counties have no hospitals; six operate institution type nursing homes, but have no public facilities for surgical or maternity cases; and one county has a contractual agreenent with a private facility to take care of county cascs. GREENFIELD, op. cit. supra, at 25.

18 See text accounpanying notes 24-32 infra.

19 Various agencies are employed by the counties for collection of reimbursement claims against patients and their responsible relatives: thirty-six counties' bospitals have cither a collection department or a social service responsible for collections. In twenty-two counties, the district attorney, county counsel, county welfare department, or some other county office is either solely responsible for or slares responsibility with hospital staffs for collection. Twentythree counties employ commercial collection agencies either as sole collector or to carry on where county offices have been unsuccessful. See Greenfiedd, Property Litens for CountY Hospital Care-A Colnection Toor table A-1 (University of California Legislative Problems No. 8, 1961).

20 One rather recent survey indicates that collections for care in county lospitals usually offset a rather small percentage of the expenditures. Id. at table A-3. 
utilized." This Comment will refer to these liens as "liens by grant," since they arise from a conveyance by the lienee to the county. Judgment and execution liens imposed in connection with lawsuits enforcing the liability of a patient or a relative may also provide some aid in collecting moneys due the county for hospital care. Consonant with the traditional emphasis on local control of general relief, policies such as the conditions under which liens will be taken, the kinds of property which may be subjected to encumbrance, and other policies relating to the time and manner of imposition and enforcement of liens by grant and of judgment and execution liens, have remained largely matters for county discretion. The result has been a wide variation im policy from county to county. ${ }^{22}$

The 1963 amendments limit the discretion of counties to take liens by inposing restrictions on the time and manner of enforcement in some cases and by substantially withdrawing the authority to impose hens in others. The approach of the legislature has been not to undertake exclusive administration of welfare lien policies by the state but to authorize continued local discretion regarding these policies subject to substantial limitations. Hence, the question of overriding importance to county and state administrators alike is whether the amendments are sufficiently free from ambiguity that they can be uniformly applied by the counties. The following discussion will place considerable emphasis upon that question.

\section{NATURE OF LIABILITY UNDERLYING COUNTY HOSPITAL LIENS}

Analysis of the reimbursement problem begins with two considerations. First, county hospital care often is furnished to patients who can pay for at least a part of the care provided. Second, the law, in many cases, requires that patients who can pay must pay, and the county must take affrmative steps to collect from them.

\section{A. Hospital Care For the Patient Who Can Pay}

The problem of reimbursement arises in the first place because county hospitals often provide services to persons who have some ability to pay for their care. For instance, some patients have real or personal property which, even if not sufficient to finance private care, nuay be sufficient to partially defray the expense of providing county hospital care. Some patients who were penniless at the time care was provided by the county thereafter acquire property, for instance by inheritance. Finally, patients sometimes have relatives who own real or personal property sufficient to absorb all or part of the cost of care received

21 According to a recent tabulation, only eleven counties do not ask patients to sign liens as security for payment of their lrospital bills. Id. at table A-2. These counties are Alpine, Imperial, Nevada, Placer, Pluinas, San Bernardino, San Luis Obispo, Santa Barbara, Tehama, Trinity, and Yolo. Ibid. Instead of imposing liens, these counties apparently attempt to obtain payment during the lifetime of the patient or his responsible relatives, then file an unsecured claim against the estate of a deceased patient or bis relatives. Id. at 22 .

22 E.g., some counties make the patient's granting of a lien a requisite for admission to the hospital; others take a lien anytime they can get it prior to payment of the bill. Id. at 24 . Soune counties have eharged interest on outstanding billings, others bave not. Id. at 25 . 
by the patient..$^{23}$ Lien policies attach some importance to the patients' varying sources of support by prescribing different consequences depending roughly upon whether the person seeking medical care receives non-medical support (1) from general relief or private means; or (2) from payments under one of the categorical aid programs. In addition, lien policies isolate for special treatment persons ehigible for medical care under the MAA program.

In general, the first classification refers to three kinds of patients. (1) There are residents of the county who, having no substantial private means, rely heavily upon general relief payments to satisfy everyday needs. Since they are no better able to provide medical care for themselves than other forms of support, these persons require county medical care under the general relief program. (2) There are residents of the county that have private means which are sufficient to satisfy non-medical support needs for themselves and their dependents but are inadequate to provide for inedical needs. ${ }^{24}$ These persons often are termed "medically indigent," because, although they normally do not receive general relief, they require such relief for medical needs. (3) Finally, there are persons who have sufficient private ineans both to provide for their own non-medical support and to obtain private medical care, but who are compelled for special reasons to seek medical care from the county. ${ }^{25}$ For example, county medical care of persons with sufficient private means has been upheld in emergency cases, ${ }^{26}$ in cases where private facilities are not adequate or are not available to take care of patients, ${ }_{2}^{27}$

23 It has been held that the fact that an indigent has legally liable kindred able to maintain him does not preclude him from obtaining relief from the county; though the county's mandatory duty to reheve and support all indigent residents is not limited to cases where an indigent is without a responsible relative with the ability to support him, the duty does not extend to those cases where responsible relatives are actually supporting and reheving the indigent. County of Los Angeles v. Frisbie, 19 Cal.2d 634, 122 P.2d 526 (1942).

24 The important early case, Goodall v. Brite, 11 Cal. App. 2d 540, 549, 54 P.2d 510, 514-15 (1936), provides this example: "We can visualize the head of a family who has cmployment and can keep it-an honest worker, frugal and thrifty, who supports his family, educates his children and has perhaps acquired an equity in a modest home. If he is injured, not in the course of his employment, the family income stops and he may require hospitalization and may lack the funds with which to enter a private institution. Must it be said that he should be refused admission to the county hospital because he is not a pauper when if he were a pauper he would be admitted without question? ... [W]e are compelled to hold that a patient in need of hospitalization, who cannot himself, or through legally liable relatives, pay the charges of a private institution, should be admitted to the county hospital because the care of such sick or injured promotes the public health and general welfare of the community in which he lives."

25 As a rule, both the California statutes and the Cahifornia Constitution require persons with adequate private means to seek private care. CaL. WETFARE \& INST'NS CODE $\$ 2500$ (sct forth at note 1 supra) instructs the counties to provide support to indigent persons unless otherwise supported. The primary constitutional objection to the provision of county hospital care for persons with adequate private means is that such care constitutes a gift of public moneys in violation of CAL. Const. art. IV, §31. E.g., in Goodall v. Brite, 11 Cal. App. 2d 540,54 P.2d 510 (1936), the court upheld an injunction against the Kern County board of supervisors, prohibiting thein from accepting full-pay patients into the county hospital. The exceptions which have arisen occur in cases where care is provided by the county under circumstances suggesting that a public purpose is served by provision of medical care by the county.

28 Griffen v. County of Colusa, 44 Cal. App.2d 915, 113 P.2d 270 (1941); Goodall v. Brite, 11 Cal. App. 2d 540, 54 P.2d 510 (1936); 8 Ors. Car. Arr'y Gen. 246 (1946).

27 Calkins v. Newton, 36 Cal. App. 2d 262, 97 P.2d 523 (1940); 19 Ors. Cal. Atr'y Gen. 36 (1952). See also 29 OPS. CaL. Arr'y GEN. 183 (1957), to the effect that provision of county services is permissible if full rates are charged for the services. 
in psychiatric and other custodial cases, ${ }^{28}$ and in tuberculosis cases. ${ }^{29}$

Aside from these classes of persons, many county residents not possessing adequate private means for support receive public assistance under one of the several statewide categorical aid programs. Assistance under AFDC, OAS, AB, APSB, or ATD may include some funds for medical care..$^{30}$ Many recipients of aid under these programs, however, must rely upon county hospitals for medical care either not covered by the programs or for which the monetary allowances are insufficient. ${ }^{31}$ In addition, patients eligible for MAA may face this problem. Aged residents may be eligible for funds for long term inpatient hospital care under the MAA program, but many of them must rely upon county hospitals for medical care not covered by MAA. For instance, MAA provides funds for outpatient care only to patients discharged from inpatient care. ${ }^{32}$ In many cases, therefore, there are patients receiving categorical aid who nevertheless are medically indigent.

\section{B. Duty of the Patient or Relatives to Pay and of the County to Collect}

At common law in California, an indigent who received public medical care apparently had no obligation to reimburse the public entity for such care. ${ }^{33}$ From the patient's lack of hability at common law, it follows that the patient's relatives, too, were not liable for the cost of public medical care. Statutes now impose liability to some extent upon the patient and his responsible relatives.

The statutory basis for liability of a person receiving medical care under county general relief programs is embodied in California Welfare and Institutions Code Section 2603. It provides that if a person who has received general relief acquires property, the county shall have a claim for a "reasonable" amount against the patient for the relief moneys expended. Although section 2603 has

28 Cal. Welfare \& INsT'Ns Code $\$ \S 6000-05$; see Goodall v. Brite, 11 Cal. App. 2d 540, 54 P.2d 510 (1936).

20 Cal. Health \& Safety Code $\$ \S 3298,3300$; see Greenfield, op. cit. supra note 19, at 12.

30 Recipients of $\mathrm{AFDC}, \mathrm{OAS}, \mathrm{AB}, \mathrm{AFSB}$, and ATD may receive "special needs" grants and allowances as part of the assistance provided under those programs specifically earmarked for satisfying medical needs. See, e.g., State Department of Social Welfare Old Age Security Manual §§ A 206.1-.94; Aid to the Blind Manual \$§ B-205-08; Aid to Families with Dependent Children Manual $\$ \$ C-205-06$. In addition, recipients of all categories of categorical aid may receive allowances for some outpatient medical care under the PAMC program. CAL. WELFARE \& INST'NS CODE $\$ \$ 4500-4605$; see note 9 supra.

31 Care covered by PAMC excludes all inpatient care, CAI. WELFARE \& INST'NS CODE $\S 4502$; it also excludes maternity care and care for tuberculosis, venereal disease, and mental illness. State Department of Social Welfare Public Assistance Medical Care Manual MC-040. Indeed, the availability of county facilities to provide for these kinds of cases, except inental illness, appears to have been a primary reason for excluding them from PAMC coverage. ten Broek, supra note 9, at 575-77. See also the State Department of Social Welfare Manual sections, supra note 30 .

32 CaL. Welfare \& Inst'Ns CODE $\$ 4722$. The 1963 amendment to $\$ 4722$ retains this omission from MAA care by providing that: "In establishing the scope and limitations of medical assistance to be provided pursuant to this chapter, the Social Welfare Board shall be himited to providing medical care to an aged person who requires care in a hospital or a nursing home and outpatient care for such aged person following discharge therefrom." Cal. Stat. ch. 510, $\S 36$ (1963).

33 County of Alameda v. Janssen, 16 Cal. 2d 276, 106 P.2d 11 (1940) ; County of Los Angeles v. Security First Nat'l Bank, 84 Cal. App. 2d 575, 191 P.2d 78 (1948). 
been held to make a patient liable for the cost of county hospital care, ${ }^{34}$ that liability has been limited to property acquired by the patient after treatment commences. $^{35}$ Since the scope of section 2603 is limited, the question arises whether the county can reach property which the patient owns prior to commencement of and during treatment. No doubt the county can reacli this property if, prior to or during treatment, it has obtained a reimbursement agreement in which the patient agrees to become hable for the hospital costs. ${ }^{83}$ If the county has not obtained a reimbursement agreement, its position is uncertain, because there is no statute expressly entitling the county to reimbursement out of property which the patient owns prior to or during treatment. If the courts conclude, as a result of this hiatus, that the patient is not liable other than by agreement for hospital care with respect to this property, then the common law rule of non-liability prevails with respect to that property. ${ }^{37}$ If the courts are confronted with this precise question, however, it is possible that they will infer authority for the county to enact an ordinance imposing hability from the statutes delegating the management and control of county lospitals to the boards of supervisors. ${ }^{38}$

A county hospital patient's spouse, parent, and adult child may be responsible for reimbursing the county for the cost of county lospital care given to the

34 County of Los Angeles v. Read, 193 Cal. App. 2d 748, 14 Cal. Rptr. 628 (1961); County of Los Angeles v. Security First Nat'l Bank, supra note 33; 33 OPS. CAI. ATT'y GeN. 158 (1959).

35 In County of Los Angeles v. Read, supra note 34, an allegation that the patient acquired the property against which satisfaction was sought subsequent to the commencement of treatment was held essential to the county's stating of a cause of action under CAT. WELFARE \& INST'NS CODE $\$ 2603$.

36 Cat. Wetfare \& Inst'ns Code \$ 2601. See Brown v. County of Los Angeles, 77 Cal. App. 2d 814, 176 P.2d 753 (1947).

37 There is some language hinting that CAL. WeLFARE \& INST'NS CODE \$ 2603 makes a patient hable for reimbursement with respect to his property whenever it was acquired; c.g., 8 OPS. Cal. ATT'y Gen. 219 (1946). The writer has found no holding based on such an interpretation; and the holding in County of Los Angeles v. Read, $193 \mathrm{Cal}$. App. 2d at 748, 14 Cal. Rptr. at 628 (1961), seems clearly contra.

The hiatus, if unfilled by local legislation, may mean that a county that has failed to secure an agreement from the patient prior to or during hospital treatment may he precluded from thereafter subjecting property owned by the patient at that time to hability by the traditional judicial procedures.

38 Perhaps the major question is whether counties have the authority to enact local legislation making the patient liable for reimbursement of the cost of county hospital care. Two possible bases for such authority are (1) implications flowing from state laws placing county hospitals under the management of the counties, and (2) CAL. CoNsT. art. XI, \& 11, which provides, "any county, city, town, or township may make and enforce within its limits all such local, police, sanitary, and other regulations as are not in conflict with general laws."

The authority of counties to enact local legislation, making the patient liable for reimbursement of the cost of county hospital care, was inferred by the court in Goodall v. Brite, 11 Cal. App. 2d 540, 54 P.2d 510 (1936), from the provisions of PorItical Code $\$ 4223$ (the predecessor of CAL. HEALTH \& SAFETY CODE $\$ \$ 1441$ and 1454) wbich places county hospitals under the management of the respective county boards of supervisors. The opinion even indicated that the supervisors, in managing the hospital, assume the responsibilities of trustees and must collect from the patient. If the Goodall court's inferences are valid, the passage of CaL. HEALTH \& SAFETY CODE § 1473 eleven years after the Goodall decision strengthened the argument that the counties possess the implied authority locally to create liability. Section 1473 provides that the board of supervisors may fix the rates to be charged patients admitted to a couny hospital and may direct any county officer to collect the amounts due the county for hospitalization and medical care.

Also relevant, in light of the Goodall decision, is Cal. Healtr \& Safety Cone $\$ 1445$ 
patient. California Welfare and Institutions Code Section 2576 provides that, "all aid rendered by the county under this chapter shall be a charge against the spouse, parent and adult child of the recipient thereof and the county rendering aid shall be entitled to reimbursement therefor. . . ."39 A condition precedent to liability is a finding by the board of supervisors that the relative was financially able to contribute both at the time medical care was granted and when reimbursement is sought. ${ }^{40}$ This requirement may have lost much of its vitality, however, as a result of a recent loolding that there is a presumption that the county has made such a finding. ${ }^{41}$ Although the provisions of other codes establish the civil and criminal responsibility of persons to support certain relatives, ${ }^{42}$

which authorizes counties "to provide the means to meet promptly and adequately the health needs of [indigents] ... to the end that such persons will not become public charges at the greater expense of those resources set aside for the pubhic health and welfare." "To provide the means" may include managing county hospitals and therefore imply the power to establish patient liability within the meaning of Goodall. Moreover, the limiting of liability to the extent of the patient's ability to pay may supplement county finances needed to meet "adequately the health needs" of indigents while avoiding hability so burdensome that the patients become "public charges."

The Goodall court did not base its conclusion with respect to the authority of counties to provide for patient hability upon CAL. ConST. art. XI, $\$ 11$. It seems doubtful that this provision provides the necessary authority. It has been suggested that art. XI, § 11 confers power only to make and enforce penal ordinances. Peppin, Municipal Home Rule in California III: Section 11 of Article XI of the California Constitution, 32 CaIIF. L. Rev. 341, 342-60 (1944). With respect to county hospitals, a similarly narrow interpretation was placed on art. XI, $\S 11$ in the early case, Von Schmidt v. Widber, 105 Cal. 151, 38 Pac. 682 (1894), which held that the section did not authorize a city to purchase land for a smallpox hospital. If the powers needed to establish patient hability may be analogized to the powers needed to establish a county hospital, it is arguable that counties may not rely on art. XI, $\S 11$ for authority. For cases indicating a somewhat broader reading of art. XI, §11, though not specifically with respect to county hospitals, see Farley v. Stirling, 70 Cal. App. 526, 233 Pac. 810 (1925); 28 Ops. Cal. AtT'y Gen. 282 (1956).

A finding that counties may establish patient hability, either under art. XI, $\S 11$ or by virtue of the imphications flowing from the county hospital statutes, sets the stage for a further problem. It is at least arguable that any local legislation is preempted, since the state seems to have occupied the field with CAL. WeLFare \& INsT'Ns CODE $\$ 2603$.

In determining whether the courts will adopt either of the approaches suggested above, it should be noted that the language of the Supreme Court of Cahfornia in Department of Mental Hygiene v. Kirchner, 60 A.C. 704, 338 P.2d 720, 36 Cal. Rptr. 488 (1964) (discussed in note 43 infra) is sufficiently broad to indicate that, in future cases, the court not only may refuse to infer patient liability where the statutes do not expressly impose it, but may hold all patient liability unconstitutional.

While a conclusion denying the county authority to estabhish patient liability might be undesirable from the standpoint of the county, treatment of patients im such circumstances does not necessarily result in an unconstitutional gift of public moneys. In Goodall it was held not to be a gift of public moneys to treat without reimbursement (1) persons who cannot pay for private care and cannot contribute anything towards pubhic care; and (2) persons who cannot pay for hospitalization in private institutions but who can pay something towards their care and treatment in county hospitals. The case indicated that only those who can pay in full for private care, assuming private facilities are available, may not constitutionally be admitted to county hospitals.

39 Aithough the relative is fully liable, the board of supervisors can compromise any claim if such action is warranted by the present financial condition of the relative. CAI. Health \& Safety CODE $\$ 1473$.

40 Car. Welfare \& Inst'ns Code $\$ 2576$. See Turnboo v. Santa Clara County, 144 Cal. App. 2d 728, 301 P.2d 992 (1956).

41 County of Los Angeles v. Read, 193 Cal. App. 2d 748, 14 Cal. Rptr. 628 (1961).

42 Cal. Civ. Code $\$ \$ 206,206.5-.7$; Cal. Pen. Code $\$ 270 \mathrm{c}$. 
it seems settled that section 2576 is the exclusive source of liability of relatives for medical care supplied by the counties. ${ }^{43}$

There is some authority to the effect that the counties are obligated to press patients and responsible relatives for reimbursement for hospital care, at least to the extent that the patient or responsible relative is able to make reimbursement. ${ }^{44}$ Accordingly, collection for county hospital care constitutes an integral part of the administration of most county hospitals. ${ }^{45}$

\section{II}

\section{AUTHORITY OF COUNTIES TO EMPLOY LIENS AS COLLECTION TOOLS}

Difficulty in making collections for reinbursement for the cost of county hospital care ${ }^{46}$ makes property liens important as collection tools. ${ }^{47}$ While judgment and execution liens are generally available to counties, most seem to prefer liens by grant. ${ }^{48}$ This preference may be explained, in part, by the exemption from execution of property which probably would not be exempt from foreclosure of a lien by grant. ${ }^{49}$ It also may be founded, in part, upon the realization that the adoption of judgment and execution liens as the regular form of security would mean use of the lawsuit as the regular method of collection. Numerous problems might be created by such a policy. A multitude of court actions for the collection of reimbursement claims could create a drain upon county time and money considerably greater than that created by the enforcement of liens by grant. The applicability of the statute of limitations might produce results disadvantageous

43 County of San Bernardino v. Simmons, 46 Cal. 2d 394, 296 P.2d 329 (1956) (disapproving contrary implications contained in Garcia v. Superior Court, 45 Cal. App. 2d 31, 113 P.2d 470 (I941) and Kelley v. State Board of Social Welfare, 82 Cal. App. 2d 627, 186 P.2d 429 (1947)).

The recent California Supreme Court decision in Department of Mental Hygiene v. Kirchner, 60 A.C. Cal. 2d 704, 338 P.2d 720, 36 Cal. Rptr. 488 (1964), at the very least, questions the constitutional validity of loolding relatives liable for the cost of a patient's county lospital care. This Comment will consider liability of relatives for county hospital care in spite of the rather far-reaching implications of the Kirchner decision, since Kirchner dealt with institutional care at the state level of insane persons rather than with the problem of county lospital care.

44 See Goodall v. Brite, 11 Cal. App. 2d 540, 54 P.2d 510 (1936) (dictum). In Reichle v. Hazie, 22 Cal. App. 2d 543, 71 P.2d 849 (1937), the defendant in a personal injury case argued that the plaintiff was not entitled to special damages because loe had been treated at a county lospital; the court held, citing Goodall, that the county liad a duty to collect charges from the plaintiff-patient; treatment therefore was not gratuitous and special damages could be awarded. However, since it appears that the county had, by ordinance, already provided for the collection of charges in that case, the broad loolding probably was not necessary to decide the case. The model case, perhaps, would be a taxpayer suit against a county board of supervisors which had refused to collect charges for county lospital care. Such a case is not likcly to arise, since most counties lave aggressive collection policies. GreENFIEdD, op. cit. supra note 19, at 14-15.

45 See note 19 supra.

40 See note 20 supra.

47 The descriptive term "collection tool" is borrowed from GreENFIELd, op. cil. supra note 19.

48 See id. at 22-30. Although Miss Greenfield's discussion does not elearly distinguish between liens by grant and liens following judgment, enough is said to indicate a distinct county preference for liens by grant.

49 See Cax. Code Crv. Proc. $\$ \$ 690-690.25,690.50$; Danielson v. Stokes, 214 Cal. App. $2 d$ 234, 29 Cal. Rptr. 489 (1963); Willen v. Willen, 121 Cal. App. 351, 8 P.2d 942 (1932). 
to both the county and the person liable for reimbursement, by promoting the filing of lawsuits soon after commencement of treatment. ${ }^{50}$ It is possible that the amount of property which legally may be reached by a lawsuit is less than that which may be encumbered by liens by grant because of the limitation of section 2603 to after-acquired property. ${ }^{51}$ Finally, it would seem that lawsuits, more than even compulsory written agreements, add to whatever other psychological hardships already are suffered by a recipient of medical care under a general relief program. ${ }^{52}$ Because of the counties' greater use of liens by grant, those liens will receive special emphasis in this Comment.

\section{A. Ground Rules Relating to General Relief Programs}

Since county hospital care is provided by counties as part of their general relief programs, the authority to subject the property of patients and responsible relatives to liens for reimbursement of the cost of county hospital care originates in the general rehef statutes. ${ }^{53}$ The "ground rules" discussed in this subdivision are those rules contamed in the statutes which apply generally to all patients receiving county hospital care. ${ }^{54}$ They will be considered first as they relate to the patient as lienee and second as they relate to the relative as lienee.

50 Cat. Code Crv. Proc. $\$ 345$ provides a four year limitation period. The period begins to run upon the patient's attaining "sufficient financial ability to pay the county" subsequent to treatment. County of Los Angeles v. Security First Nat'l Bank, 84 Cal. App. 2d 575, 191 P.2d 78 (1948). If the patient has acquired sufficient ability to pay soon after treatment, a resulting "early suit" by the county may set back whatever financial recovery the patient has made since treatment. While counties may be inclined to follow up judgments with immediate execution and sale, counties that have acquired liens by grant, in which the statute of limitations has been waived, lave often shown a willingness to be more patient. See note 59 infra. There may also be disadvantages for the county if it decides against inmediate sale. Though the opportunity to levy execution could continue indefinitely following a judgment in the county's favor, CAL. CoDe Crv. Proc. $\$ \$ 337.5,681$, 685, the burden would be upon the county to maintain constant contact with the patient to discover any newly acquired property. If the judgment were recorded in order to obtain a lien upon any real property not already owned by the patient at the time of judgment, similar diligence would seem necessary for the county to maintain its priority as against other creditors of the patient. See Hertwick v. Fearon, 180 Cal. 71, 179 Pac. 190 (1919).

If the patient las not acquired sufficient ability to pay until long after treatunent, county collection officers face a dilemma: On one hand, the county cannot maintam an action pursuant to $\$ 2603$ until the patient acquires sufficient ability to pay. On the other land, the statute of limitations begins to run, according to Security First Nat'l Bank, as soon as the patient attains the ability. The need for continuous information concerning assets acquired by the patient and the determination of what level of non-exempt assets constitutes "financial ability to pay" would seem to create particularly difficult administrative problems for the county.

51 As indicated in the text accompanying notes 35-38 supra, it remains unsettled whether a patient is liable, in the absence of an agreement, with respect to property which cannot be reached by $\$ 2603$.

52 In comparing the advantages of liens following larvsuit with those of liens by grant, it should be mentioned that apparently the county does not enjoy, with respect to either type of lien, any priority over non-public creditors whose liens are prior in time. The absence of special priority seems expressly recognized, for instance, by CAL. WELFARE \& INST'Ns CODE § 219.

53 This principle is codified in CaL. Hearte \& SAFETy Code $§ \S 1473-74$.

54 Certain additional rules discussed in a later section of this Comment modify the general relief rules with respect to situations involving patients who are recipients of $O A S, A B$, APSB, ATD, AFDC, or are eligible for MAA. See subdivision IIB of the text, infra. 


\section{Patient as Lienee}

California Welfare and Institutions Code Section 2601 authorizes counties to require liens by grant with respect to both the real and the personal property of general relief recipients to secure reimbursement for relief payments. Section 2601 is expressly made applicable to cases in which the "relief" provided is county liospital care. ${ }^{55}$ The grant of the lien to the counties commonly is effectuated by a "reimbursement agreement," which typically consists of: (1) a written agreement to reunburse the county for general relief moneys expended on behalf of the patient; (2) a grant to the county of a lien upon all personal and real property owned then or thereafter by the patient; and (3) a waiver of the statute of limitations. ${ }^{56}$ Some limitations upon the enforcement of liens by the counties existed prior to 1963 . One self-imposed restraint may lave arisen occasionally. When the county's lien was prior to other encumbrances, the county could subordinate its lien at least to permit the patient to refinance other outstanding encumbrances against his property; and, apparently with absolute discretion, the county could subordinate its lien to others for other purposes or could reconvey the lien to the lienee patient. 57

The requirement that the patient waive "forever" the statute of limitations lias obviated its possible restrictive effect. While requiring waiver of the statute of limitations appears oppressive, the procedure probably is lawful ${ }^{58}$ and may even serve the interests of the patient; it seems to promote the almost universal county practice, in cases where the patient defaults and the encumbered property is his lome, of postponing foreclosures until the patient's death, when a secured claim is made agamst the patient's estate. ${ }^{59} \mathrm{~A}$ final qualification upon enforce-

55 Cax. Healte \& Safety Code $\$$ 1473-74 expressly make CaL. Wetfare \& INST'Ns Code $\$ \$ 2600-11$ applicable to collections for care provided by the county hospital. See also 33 Ops. CAI. ATT'y GEN. 158 (1959), loolding that $\$ \S 2600-11$ authorize counties to require liens from an OAS recipient in cases involving hospitalization in county hospitals.

56 Mlustrative is the following reimbursement agreement that was signed by the patient in Turnboo v. County of Santa Clara, 144 Cal. App. 2d 728, 301 P.2d 992 (1956): "I . . do liereby acknowledge that I liave received relief, care and maintenance and/or medical aid from the Board of Supervisors .... and that $I$ agree and intend to unake reimbursement for this and all other aid and assistance rendered me during the period of my dependency.

"I do hereby waive the limitation of any statute for the presentation of any claim for the repayment of said relief, care and maintenance and/or medical aid.

"I do hereby agree that any and all monies so paid me by the promisee shall be securcd by a lien on the following described property, or any and all other property that I may become seized of in the future; and in the event of my coming into possession of any funds or property of any kind, and if at the time of nry death I leave any estate whatsoever, I agree that that promisee shall be paid for all momies paid ine for my relief, care, maintenance and medical aid, and my executor, administrator, or personal representative is directed to pay out of my said property and estate all of said momes paid me for my relief, care, maintenance and medical aid."

57 CaL. Werfare \& INST'NS CODE $\$ \$ 2608-09$. The sections are limited by express language to liens by grant.

58 Cal. Code Crv. Proc. $\$ 345$ provides a four year statute of limitations. Althougb contrary to public policy in other jurisdictions, 47 CaLTr. L. Rev. 90 (1959), 4 Stan. L. Rev. 415, 420 (1952), waiver of the statute incorporated into an original agreement in indigent aid situations apparently not only is permissible but may be effected indefinitely without the four-year renewals required in cases involving obligations other than obligations to repay county indigent aid. See Cal. Code Crv. Proc. \$360.5.

59 See GreenFIEID, op. cit. supra note 19, at 26. Some counties wait, too, until the patient's spouse dies. Ibid. An exception ordinarily is made if the home is sold. Ibid. 
ment has been the right of the patient to redeem his property prior to public sale. ${ }^{60}$

There have been some restrictions upon the amount and kinds of property upon which the county may require a lien. Exempted from encumbrance are insurance policies up to the actual cash surrender value of five hundred dollars; fifty dollars in cash; personal effects and household furniture up to the value of five liundred dollars; a grave, crypt, or niche intended for the interment of the applicant or recipient of care; and funds up to five hundred dollars intended for funeral expenses. ${ }^{61}$

The 1963 legislature not only added to the restrictions relating to the enforcement of liens but also prohibited liens in certain cases. With respect to enforcement, the legislature made four changes. First, no interest or carrying charge may be charged in counection with any debt for county hospital care. ${ }^{62}$ Second, the patient's right to redeem his property prior to a forced sale is made unequivocal when the amount due is paid..$^{63}$ Third, county lien policies must make some allowance for the patient's desire to sell or improve his encumbered property. ${ }^{04}$ Fourth, in certain cases, the county must delay enforcement of liens agamst the homes of patients. ${ }^{65}$ The amendments lengthen the hist of circum-

60 CAL. WELFARE \& INST'NS CODE $\$ 2607$. The language of the statute suggests that its provisions are not mandatory. While it may be merely permissive insofar as it authorizes the county to permit redemption for a price less than the amount of aid expended, reason, together with some authority, commends the view that the provision is mandatory where the patient tenders the full amount of aid expended. 9 OPS. CAL. ATr'Y GEN. 120 (1946). The property may also be redeemed by the recipient's heirs. Ibid. Section 2607 apphes only to liens by grant. Redemption in eases involving execution and judgment liens seems covered by CAL. Crv. CoDE $\$ \S 2903,2905$. For the patient's redemption rights following sale, see Car. ConE Crv. Proc. \$\$ 700a-707.

61 CaL. Welfare \& INST'NS CODE $\$ 2611$, applicable to hens arising under both $\$ 2601$ and $\$ 2603$.

62 Cax. WeIfare \& Inst'ns Code $\$ 2601.5$, added by Cal. Stat. ch. 2159 , $\$ 1$ (1963). This corrects the practices of some counties. GrEENFIEID, op. cit. supra note 19, at 25 .

63 Cax. Welfare \& INST'Ns CoDE $§ 2601.5$, added by Cal. Stat. ch. 2159, § 1 (1963), provides that a statement of charges for county hospital care upon which a claim for reimbursement is based must be rendered to the patient and any lien taken by the county must be released immediately when the amount due is paid. Since CAL. WELFARE \& INST'NS CODE § 2607 is not repealed, it apparently remains within the discretion of the county to allow a patient to redeem for a price less than the full cost of care. It seems important for the county to retain such discretion, for the "amount due" is usually "all momies so paid . . . by the county." See the agreement set forth at note 56 supra.

G4 Under CAL. WELFARE \& INST'NS CODE \$ 2601.5, added by Cal. Stat. ch. 2159, § 1 (1963), the county mnst transfer hens to a new home where the patient sells his old home against which a county lien existed; in addition, if the patient borrows money against his home to make improvements on it, the county must subordinate its lien on the home to the resulting mortgage. The county need do neither of these things, however, if to do so would impair its security.

o5 Because of the patient's waiver "forever" of the four-year statute of limitations, most counties postpone enforcement of a $\$ 2601$ lien at least until the death of the patient, and sometimes until the death of his spouse. Note 59 supra. CAL. WELFARE \& INST'NS CODE $\$ 2601.5$, added by Cal. Stat. ch. 2159 , $\$ 1$ (1963), provides: "No lien taken by a county pursuant to Section 2601 for care provided to a person in a county hospital shall be enforced against the home of that person (1) during his lifetime or that of his spouse, or (2) during the minority of his children if they reside in the home, or (3) during the hifetime of any dependent adult child who resides in the lome and who is imcapable of self-support because of mental or physical disability."

This section makes many changes. In cases falling within this provision, (1) the four-year statute of limitations apparently is tolled until the conditions of the provision are fulfilled; (2) delay in enforcement, which was before a matter of grace by the counties, now is manda- 
stances under which property is inaccessible to the county by providing that liens by grant may not be taken against the home of a person for care provided him in a county hospital if he was confined to the county hospital as a result of a diagnosis of tuberculosis. ${ }^{66}$

\section{Relative as Lienee}

In cases where the county has sought to collect county hospital charges from responsible relatives of the patient, two kinds of liens may arise. First, pursuant to the hability under section 2576 of the patient's spouse, parent, or adult child, a statutory procedure is set out by which the district attorney, upon request by the county, shall bring an action against the responsible relative on the debt.07 If the court finds the relative liable, the county is entitled to both a judgment for amounts due at that time and an order enforceable by contempt requiring the payment of any sums which may become due in the future. ${ }^{88}$ Certainly the judgment for amounts already due may provide the basis for a judgment lien or execution lien upon the property of the relative.

Second, counties frequently have required written conveyances of liens from responsible relatives. ${ }^{69}$ The source of the counties' authority to require liens by grant from relatives is not clear. If section 2601 is read literally, it does not provide the authority, because that section applies only to such property as the "applicant" has. It is arguable, however, that authority has existed in spite of the wording of section 2601, because there are statutory provisions that (1) authorize the county to fix and collect the charges resulting from hospital care, ${ }^{70}$ (2) make responsible relatives liable for such charges and therefore subject them to the county collection procedures, ${ }^{71}$ and (3) expressly authorize the counties to exercise the powers conferred by section 2601 in collectimg charges for hospital care. ${ }^{72}$ No statute other than section 2601 supports a contrary conclusion. ${ }^{73}$

tory; (3) delay in enforcement is extended to cases where minor children reside in the home or an adult child who is either dependent or incapable of self-support because of mental or physical disability resides in the home. Since the provision applies to hens on the "homc of that person," it probably does not compel delays in enforcement in cases where the home is sold. This seems consistent with current county practice. See note 59 supra.

66 Cal. Welfare \& InsT'NS Code $\$ 2601.5$, added by Cal. Stat. ch. 2159, § 1 (1963).

67 CAL. WELFARE \& INST'NS CODE $\$ 2576$.

68 CAL. Wetfare \& INST'NS CoDe $\$ \$ 2576-77$.

69 GREENEIEID, op. cit. supra note 19, at 31-32.

70 Cal. Health \& Safety Code $\$ 1473$.

71 Cal. Welfare \& InsT'Ns CODE $\$ 2576$.

72 Cat. Health \& Safety Code \$ 1474.

73 If CAL. WEIFARE \& INST'NS CODE $\$ 2601$ is to be read to justify demands for liens by grant from relatives, then it follows that care may be demed patients whose rclatives refuse to execute the required grant. Hence, although existing statutes do not compel a contrary reading of $\$ 2601$, it may well be argued, as a inatter of policy, that such a reading of $\$ 2601$ unfairly penalizes patients for the recalcitrance of their relatives.

In addition, if $\$ 2601$ is read to apply to relatives, then the courts must be prepared to determine whether the restrictions on enforcement and prohibitions against certain liens which apply to hens on the property of patients transferred pursuant to $\$ 2601$ also apply to cases involving relatives. The reasons that motivated the legislature to prohibit liens on the homes of tubercular patients, for example, may not apply with equal force in cases involving liens on the homes of relatives of tubercular patients. The problem is made more complicated by the fact that the 1963 amendments prohibit liens on the property of relatives other than the spouse of a patient or parent of a minor patient. See text accompanying note 74 infra. Since these relatives are ones likely to reside in the same home as the patient, consistency seems to require that the restrictions on enforcement be applied to hens on the property of relatives at least where the property involved is a lome shared with the patient. 
The 1963 amendments include this provision: "No lien sliall be taken pursuant to this chapter against the home or other property of any relative, except for a parent of a minor or a spouse, liable for the support of a person confined in a county hospital or otherwise receiving aid under this chapter." 74 The new provision does not reduce the liability imposed by section 2576 upon the spouse, parent and adult child; but it does outlaw liens taken to secure the discharge of this liability except in the case of a spouse or the parent of a minor.

Perhaps the most perplexing problem raised by the amendment is whether its prohibitions extend to judgment and execution liens as well as to liens by grant. For three reasons it seems likely that the amendment will be read to prohibit only liens by grants: (1) literally, the plrrase "no lien shall be taken" seems to refer to the acceptance of a conveyance rather than becoming a lienor by operation of law; (2) while prohibiting counties from requiring hens by grant from certain relatives may be justified on the ground that counties should not deny hospitalization to a patient whose relative prefers not to sign a reimbursement agreement, this reasoning does not support the abolition of judgment and execution liens that arise, by definition, after the patient lias received his medical care; and (3) if the prolibition does extend to judgment and execution liens, the anomalous result is that a judgment for amounts presently due may not be enforced by the traditional procedures, but an order requiring the relative to pay future amounts is enforceable by contempt.

\section{B. Special Rules Relating to Categorical Aid Recipients}

These ground rules for imposing liens to secure reimbursement of county hospital costs are modified by additional rules applicable when the patient also is a recipient of categorical aid. The additional rules will be cousidered first as they relate to patients who receive categorical aid other than MAA, second as they relate to the relatives of such patients, and third as they relate to patients eligible for MAA and their relatives.

\section{Patient as Lienee}

No federal or state funds are available to finance the "general relief" type of county hospital care with which this Comment is primarily concerned; to the extent that reimbursement from the patient or relative is not forthcoming, the county, alone, bears the expense out of local taxes. County hospital patients who receive assistance under the categorical aid programs, OAS, AB, APSB, $A T D$, or AFDC, generally are medically indigent in the same sense as patients who are not recipients of categorical aid. Therefore, subject to the ground rules regarding the taking and enforcement of liens, it seems clear that counties liave general authority to impose judgment and execution liens and liens by grant upon the property of categorical aid recipients for county hospital care furnished to them as niedical indigents. ${ }^{75}$ Prior to 1963 , exceptions to the generally applicable ground rules were made for the benefit of some patients who were recipients of categorical aid. The law specifically prohibited imposing liens for the cost of hospitalization furnished by counties upon any personal property or personal effects or interment plots of recipients of aid under OAS, AB, or APSB. ${ }^{76}$

74 CaL. WeLFare \& Inst'ns Code \$ 2601.5, added by Cal. Stat. ch. 2159, \& 1 (1963).

76 See 33 Ors. Cal. Atr'y Gen. 158 (1959).

76 CaL. Welfare \& InsT'Ns Code $\$ \S 2226,3009,3408$. (These sections were repealed, respectively, by Cal. Stat. ch. $43, \S \S 2.6,9,38$ (1963); their substance now appears in CaL. WeLFARE \& INST'NS CODE $\$ 441$, added by Cal. Stat. ch. 43 , $\$ 1.12$ (1963)). 
Two 1963 amendments combine to indicate that the personal property of recipients of public assistance under not only $O A S, A B$, and APSB, but also ATD and AFDC cannot be reached by county liens securing reimbursement of hospital costs. California Welfare and Institutions Code Section $441^{77}$ provides, "the cost of hospitalization furnished by a county to the recipient shall not constitute a lien against the personal property or personal effects of the recipient, or against an interment plot. ..." For the purposes of section 441, "recipient" has been defined as any person receiving aid under OAS, AB, APSB, ATD or AFDC. ${ }^{78}$ In addition, California Welfare and Institutions Code Section 2611 (f) ${ }^{70}$ provides,

\begin{abstract}
There shall be exempt from the transfers and grants authorized by Section 2601 and from attachment and execution on claims under Section 2603 against property acquired by persons for the support of whom public moneys have been expended all of the following property: ... (f) Real or personal property of a recipient of public assistance ... with respect to aid or county hospital care granted after the effective date of this subdivision.
\end{abstract}

For the purposes of section 2611(f), "recipient" of public assistance has been defined as a person receiving OAS, AB, APSB, or ATD; recipients of AFDC are excluded from the definition. ${ }^{80}$

While these provisions do not absolve the patient from liability for reimbursenent for hospital care, they apparently do remove nost liens from the list of available county collection tools. By express language, section 2611(f) prohibits subjecting the personalty of recipients of OAS, AB, APSB, and ATD to either liens by grant under section 2601 or judgment and execution liens under section 2603. Apparently not prohibited by the amendnent are judgment and execution hens that might arise from county actions based upon the patient's liability for reimbursement apart from sections 2601 and $2603 .{ }^{81}$ Also conspicuously unaffected by the amendnent is property owned by recipients of AFDC. The extent to which section 441 fills the gaps left by section 2611 (f) apparently depends upon what the former section neans by "constitute a lien." No doubt "lien" does include a hen by grant under section 2601. Less clear is whether the language includes the liens that arise by operation of law upon levy of execution or recordation of judgment. The legislature's use of "constitute" rather than "take" or sone other word connoting a linitation to "grant" situations suggests that section 441 does include judgment and execution liens. ${ }^{82}$ If section 441 takes on this added meaning, then probably both gaps in section 2611 (f) are filled; that is, judgment and execution liens based on county actions to enforce the patient's liability for reimbursement apart from sections 2601 and 2603 are prohibited in cases involving recipients of any kind of categorical aid, and probably such liens based on actions under 2603 are prohibited in cases involving recipients of AFDC.

77 Added by Cal. Stat. ch. $43, \S 1.12$ (1963).

${ }^{78}$ See Cal. Weufare \& INsT'Ns Code $\$ 425$, amended by Cal. Stat. ch. 43, § 1.2 (1963). The possibility that some aspects of the respective categorical programs are not covered by $\S 425$ is suggested by a comparison of that section with 70 Stat. 848 (1956), 42 U.S.C. $\$ \S 601$, 603 (Supp. V. 1958).

70 The subsection was added by Cal. Stat. ch. 510, §11.5 (1963).

80 Cat. Welfare \& Inst'ns Code $\S 452$, as amended Cal. Stat. ch. 43, § 1.11 (1963).

81 See text accompanying notes $35-38$ supra.

82 E.g., compare the language contained in CAL. WeLFare \& INST'Ns CoDE $\$ 2601.5$, set forth in text at note 74 supra. 
With respect to real property, California Welfare and Institutions Code Section 462 , added in 1963,83 provides:

The cost of hospitalization furnished by a county to a recipient on or after the effective date of this section, and any judgment obtained by a county against the recipient to obtain repayment of such costs, shall not constitute a lien against the real property of such recipient, and no lien shall be taken therefor.

For the purposes of this section, a recipient of public assistance has been defined as a person receiving OAS, AB, APSB, or ATD. ${ }^{84}$

Section 2611(f), which also is limited to recipients of OAS, AB, APSB, and ATD, contains substantially the same prohibitions as section 462 with one exception: Section $2611(\mathrm{f})$ appears limited to liens arising under sections 2601 and 2603. However, judgment and execution liens arising from actions based on the patient's implied liability for reimbursement apart from sections 2601 and 2603 probably are covered by the section 462 language, "any judgment obtained by a county against the recipient to obtain repayment of such costs."

A partial hiatus in the law exists with respect to the real property of recipients of AFDC. Neither section 462 nor 2611 (f) applies to AFDC cases; and section 441 , which does extend to AFDC cases, relates only to personalty. Since a child recipient of AFDC is not likely to own realty, the hiatus probably will be more troublesome in cases where the parent or needy caretaker relative is receiving aid under the AFDC program and undergoes county hospital care. The absence of contrary statutory provisions indicates that the former law remains in effect and, subject to the restrictions, judgment and execution liens as well as liens by grant upon the realty of AFDC recipients for county hospital care remain permissible.

It is difficult to perceive valid policy reasons for failing to include AFDC recipients in the otherwise complete list of categorical aid recipients whose real property now may be free from liens. Such a policy seems especially dubious, since realty owned by a parent or needy caretaker relative who receives AFDC payments is likely to consist of his home-and therefore the lome of his dependent children. Whether the omission was the result of legislative oversight or a conscious policy choice is difficult to determine, particularly because it remains uncertain whether some personal property of AFDC recipients is similarly omitted from exemption. ${ }^{85}$

\section{Relative as Lienee}

The realty and personalty of relatives of recipients of OAS and AFDC are subject to liens by grant and judgment and execution liens to the extent per-

83 Cal. Stat. ch. 510, \$ 4 (1963).

84 Cal. Welfare \& Inst'ns Code $\$ 452$, as amended by Cal. Stat. ch. 43, $\S 1.11$ (1963).

$85 \mathrm{It}$ is possible, of course, that the omission from coverage of AFDC recipients was deliberate and based upon a generally restrictive attitude toward the recipients. Sucli an attitude has been manifested in other parts of the AFDC law; for instance, total property limits are more restrictive for applicants for AFDC than for applicants for other types of categorical aid. Compare CaL. WeLfare \& INST'NS CODE $\$ \$ 1520-21.3$ (relating to AFDC) with CAL. WeIfaRE \& InST'Ns CODE $\$ \S 452-57$ (relating to OAS, AB, APSB, and ATD). Where the question is whether AFDC recipients should be included in the coverage of a provision exempting real property from subjection to liens, any restrictive predisposition may be reinforced by the probability that few AFDC recipients are home owners as compared, for example, with OAS recipients. 
mitted by the ground rules governing liens imposed to secure reimbursement of the cost of county hospital care, since no statute specially immunizes their property from such liens. The relatives of recipients of AB, APSB, and ATD, however, are expressly made not liable for defraying in whole or in part the cost of hospital care rendered at a tine when the patient was a recipient of $A B, A P S B$, or ATD. ${ }^{86}$ The 1963 amendments do not change the law. ${ }^{87}$ These statutory prohibitions of liability necessarily preclude the counties from bringing an action and, therefore, imposing judgment or execution liens. Probably these prohibitions, for similar reasons, preclude counties from requiring liens by grant from relatives. Still open, apparently, is whether the prohibition of hability precludes the counties from accepting voluntary grants of liens. This question may be largely academic; if the relatives are absolved from liability, it seems unlikely that they will indulge in charitable conveyances to the county.

\section{MAA: Special Problem}

\section{a. Patient as Lienee}

The Medical Aid to the Aged (MAA) program is designed to provide longterm medical services to aged persons not otherwise able to finance such care. ${ }^{88}$ Generally, MAA payments are a composite of federal, ${ }^{80}$ state, ${ }^{00}$ and county ${ }^{01}$ contributions; hence, county liens under the general relief laws to secure reimbursement for MAA payments have been not only inapposite but specifically prohibited. ${ }^{22}$

It sometimes has happened, however, that a patient, though eligible for MAA payments at the time of hospitalization, received care either at that time or at some time in the past which was paid for solely by county funds. One example resulted from a limitation in the coverage of the MAA law prior to 1963. Under that law, even where the patient was eligible for MAA upon entering the hospital, no MAA payments could be made during the first thirty days of confinement in the hospital..$^{93}$ Apparently, any hospital care provided by the county was provided pursuant to the general relief provisions rather than under the MAA program. Prior to 1963, the law did not prevent the imposition of liens upon the

86 CaL. WELFARE \& INST'NS CODE $\$ \$ 3011,3411,4011$.

87 CAL. WELFARE \& INST'NS CODE $\S 3411$, which prohibits counties from holding relatives of recipients of APSB liable for county hospital care furnished to the recipients, lias been repealed by Cal. Stat. ch. $43, \S 39$ (1963). This action effects no change in the law, however, because CAL. WELFARE \& INST'NS CODE \& 3011, which makes the identical prohibition with respect to recipients of $A B$, lias been amended to apply also to recipients of APSB by Cal. Stat. ch. 43, § 10 (1963). CaL. Wetfare \& Inst'vs CoDe $\$ 4011$, which prohibits counties from holding relatives of recipients of ATD hable for county hospital care furnished to the recipients, is not affected by the new legislation.

88 See note 10 supre.

8949 Stat. 620 (1935), 42 U.S.C. $\$ \S 301-06$ (1958); 76 Stat. 197 (1962), 42 U.S.C. $\$ \$ 1381-85$ (Supp. IV 1962) ; CAL. WEIFARE \& INST'NS CODE $\$ 4751-52$. Federal participation is made a sine qua non of California's MAA program by CAL. WeLfare \& INST'Ns CODE $\$ 4705$.

90 CAL. WELFARE \& INST'NS CODE $\$ 4750$.

91 CaL. WELFARE \& INST'NS CODE $\$ 4753$.

92 CAL. WELFARE \& INST'NS CODE $\$ 4736$.

93 Cal. Welfare \& Inst'ns Code $\$ 4722$. 
property of either the patients or responsible relatives, to secure reimbursement for the care thus financed by general relief funds. ${ }^{94}$

Section 2600.5, added to California Welfare \& Institutions Code in 1963, in part provides,

The policies established under Section 2600 shall not deny needed care in a county hospital ... to any person who meets the ehgibihity requirements for medical assistance for the aged under the provisions of Chapter 1 (commencing with Section 4700) of Part 4 of Division 5, and shall not require the application of any property of such a person to his support or the taking of any hen upon that property.95

Although the language of the statute is far from clear, the underlying policy undoubtedly is that the hospitalization of aged persons who will be receiving MAA payments for hospital care should not depend on their compliance with conditions relating to property ownership normally placed upon county hospital patients. Hence, if a patient applying for admission to a county hospital is eligible for and can expect to receive MAA payments to finance the cost of his lospitalization, section 2600.5 prohibits the county from denying admission on the ground that the patient refuses to convey a lien by grant to the county.

The statute's reference to "policies established under Section 2600" probably means that the amendment also makes it improper for a county to subject the patient to later liens imposed pursuant to section 2603. Whether the section also exempts the patient from any liability at all is problematical. Since section 2600.5 prohibits "application of any property" of a person eligible for MAA to his support and since the enforcement of any liability would seem to require the "application of property," the probable result is that persons eligible for MAA are immune from all liability for county lospital care in cases covered by section 2600.5 .

The cases on which the amendment might have had the greatest impact are those in which no MAA payments could be made during the first thirty days of confinement. Future cases of this kind will not arise, however, simce the coverage of MAA was extended in 1963 to include payments for this period. ${ }^{96}$ Because the broad language of section 2600.5 applies to "any person who meets the eligibility requirements for medical assistance for the aged," it is difficult to know the outermost limits of coverage under the section. For instance, if a person seeks county hospital care not covered by MAA, but otherwise meets the qualifications of an MAA recipient, it is unclear whether he is "eligible for MAA"

04 The liability of relatives in these situations is for reinbursement of county general rehef expenditures and should not be confused with the hability of adult children for reimbursement of MAA payments. See CAL. WEIFARE \& INST'NS CODE $\$ 4735$.

95 Added by Cal. Stat. ch. 510, § 11 (1963).

96 The amendment to Cac. Welfare \& InsT'Ns Code $\$ 4722$, Cal. Stat. ch. 510, $\$ 36$ (1963), retains the provision that no cost of care shall be paid for under MAA for the first 30 days of confinement in a hospital. However, Car. Welfare \& INST'Ns CODE $\$ 4722.1$, added by Cal. Stat. ch. 510, \&37 (1963), as amended Cal. Stat. ch. 2166, § 8 (1963), begins by stating: "(a) Notwithstanding the provisions of Section 4722 , payment shall be inade for the first 30 days of care if confinement occurs in a county hospital ...." Until the cost of medical assistance exceeds $\$ 2000$, such assistance provided during the first 30 days consists of county and federal funds. State contributions are added only after $\$ 2000$ is exceeded. CaL. WELFARE \& INST'Ns CODE $\$ 4753.1$ added by Cal. Stat. ch. 510, 339.5 (1963), as amended, Cal. Stat. ch. $2166, \S 10$ (1963). Notwithstanding the lack of state participation for the first $\$ 2000$, these are MAA payments which may not constitute a lien on the patient's property. CAL. WELFARE \& INST'NS CODE $\$ 4736$. 
within the meaning of section 2600.5 and therefore entitled to care free from the imposition of judgment or execution liens or the requirement of liens by grant. ${ }^{97}$ In addition, it is uncertain whether a patient now seeking hospitalization and now eligible for MAA can demand that the county reconvey or release liens imposed or granted in connection with prior hospitalization at a time when the patient was not ehigible for MAA. Finally, if a patient enters a hospital at a time when he is ineligible for MAA, then later becomes eligible, it is not certain whether the county inust, upon the patient's becoming eligible, release or reconvey any liens upon the patient's property. A reading of section 2600.5 to require the release of county liens would seem undesirable at least if the patient does not become eligible until after his discharge from the hospital. It would seem to be in the interest of counties attempting to comply with such a reading of the statute to fashion their hen policies to avoid acquiring, in the first place, liens which they would later be compelled to release or reconvey. Yet the prospective eligibility or non-eligibility of a patient after discharge would seem so conjectural that county hen policies might have to rest upon clairvoyance to comply with the statute.

\section{b. Relative as Lienee}

If cases arose prior to 1963 in which a person eligible for MAA received hospital care which was not covered by MAA but was furnished pursuant to the general relief provisions, responsible relatives were liable for reimbursement and their property subject to liens under the general relief ground rules. The MAA law did not prevent this result. ${ }^{98}$

However, the 1963 amendment to the MAA law provides, "No relative shall be held legally liable to support or to contribute to the support of any applicant for or recipient of assistance under this chapter."99 The amendment expressly applies when the patient is receiving MAA payments. The applicability of the amendment is less clear if a patient, who has applied for MAA and meets the eligibility requirements of the program, is furnished hospital care under the general relief provisions because MAA does not cover the particular medical services received. Arguably, the amendment's reference to "applicant" is intended to apply only to cases in which the application is eventually approved and payments are received. The statute's use of both the words "apphicant" "and "recipient" seems fully justified, however, only if "applicant" is given broader meaning. It seems reasonable to say that, if the patient has "applied" for MAA and meets the MAA eligibility requirements, even though he cannot receive payments for the specific care in question, the amendment absolves his relatives from liability for the care furmshed. The prohibition of liability resulting from this interpretation of the

97 It at least seems clear that the patient need not in fact be receiving MAA payments but need only be eligible for MAA for $\$ 2600.5$ to apply. State Dep't of Social Welfare Bull. No. 620-H (MC) (revised) at p. 6 (1963): "Pursuant to . . . [California Welfare \& Inst'ns] Code Sections 462 and 2600.5 , no county may have a policy which . . . requires a lien as a condition of admission from a person eligible for MAA, regardless of whether or not the person actually apphes for MAA." See also California State Dep't of Social Welfare Circular Letter No. 1376 (MC), at p. 4 (1963).

98 Former CAL. Welfare \& INST'NS CODE $\$ 4735$, repealed by Cal. Stat. ch. $510, \S 37.7$ (1963), related only to the liability of responsible relatives in cases where the patient was receiving MAA payments.

99 CAL. Welfare \& Inst'ns Code $\$ 4735$, added by Cal. Stat. ch. 510, $\$ 37.8$ (1963). Former section 4735 was repealed by Cal. Stat. ch. $510, \S 37.7$ (1963). 
statute, of course, would preclude a county from imposing liens upon the property belonging to relatives of MAA applicants.

\section{Retroactive Operation of the 1963 Amendments}

Neither the federal nor the state constitution prohibits retrospective legislation as such. ${ }^{100}$ In the unique case, County of Los Angeles v. Jessup, ${ }^{101}$ however, a statute prohibited tlie creation of a debt for Old Age Security payments and directed counties to reconvey to OAS recipients any hens that had been imposed to secure reimbursement for these payments. The statute was declared unconstitutional because it operated retroactively with respect to the already existing liens. The Supreme Court of California stated two grounds in support of the decision: First, insofar as the law applied to liens created by written agreements between the county and recipient, the requirement of reconveyance of existing liens constituted a violation of the federal constitutional prolibition against impairment of contracts. This portion of the Jessup liolding later was expressly overruled. ${ }^{102}$ Second, the required reconveyance of liens constituted a gift of public moneys contrary to Article IV, Section 31 of the California Constitution since non-severable provisions of the statute required reconveyances (1) in cases where the recipient had passed encumbered property on to an lieir or grantee and the release of the lien would therefore benefit these persons; and (2) in cases where the recipient had not been qualified for county relief in the first place because he owned more than the maximum allowable property or was in some other respect not qualified. In both of these situations, said the court, the statute, in effect, compelled the county to release a lien in favor of persons who were ineligible for aid. This writer has not discovered any case discrediting the second Jessup ground. Therefore, to the extent that the 1963 amendments apply retroactively so as to require release or reconveyance of existing liens to persons in situations (1) and (2), the amendments are unconstitutional under Jessup.

\section{The MAA Problem}

The amendments perliaps most likely to cause problems of retroactivity are those changing the MAA law. The possible problems are manifested in three situations. First, a patient now seeking lospitalization and now eligible for MAA may have received care under the general relief statutes in connection with prior hospitalization at which time he was ineligible for MAA. ${ }^{103}$ Or he may enter a

100 Rosefield Packing Co. v. Superior Court, 4 Cal.2d 120, 47 P.2d 716 (1935); Galland v. Lewis, 26 Cal. 46 (1864).

10111 Cal.2d 273, 78 P.2d 1131 (1938).

102 County of Alameda v. Janssen, 16 Cal.2d 276, 106 P.2d 11 (1940).

103 In this situation, the statute may operate retroactively in two distinguishable ways. First, without regard to the effective date of the statute, its provisions may require release or reconveyance of hens imposed or granted in connection with prior hospitalization at a time when the patient was not eligible for MAA. Second, the prohibitions of the statute may apply to liens imposed or granted in connection with a prior hospitalization which occurred prior to the effective date of the statute. The operation of the statute seems to be the same in both cases. The feature which distinguishes the second case from the first, however, is that the liens were imposed or granted, in the second case, prior to the effective date of the statute. It is at least arguable that the statute does not operate retroactively in the second case, since the beginning phrase of $\$ 2600.5$, "The policies established under section 2600 shall not deny needed care in a county hospital," contemplates future conduct by the counties and therefore will be construed to give the entire section prospective effect. 
hospital at a time when he is ineligible for MAA, then become eligible while still receiving treatment at the hospital. In both situations, care is first administered pursuant to the general relief rules under which county liens may be imposed. In both situations, however, the patient's later eligibility for MAA at least arguably requires the county to release or reconvey any county liens then existing on the patient's property. ${ }^{104}$

Second, prior to 1963 a patient who was fully eligible for MAA nevertheless may have received the first thirty days of county hospital care under a general relief program because the MAA law then did not authorize payments under the MAA program for the first thirty days of treatment. ${ }^{105}$ A retroactive application of section 2600.5 would seen to require the county to release or reconvey any liens taken to secure reimbursement of the cost of the thirty days' care.

A third situation involves only those patients who entered county hospitals durmg the first few months preceding the effective date of section 4722.1, the amendment providing for MAA payments during the first thirty days of county hospital treatment. The state, in granting assistance to an MAA applicant under the 1963 MAA law, may pay MAA to cover care occurring within three months prior to the patient's apphication. ${ }^{106}$ The Federal Government has agreed to participate in California's MAA program under a state plan which provides for "ante-apphication" payments for care provided as far back as February 1, 1963. ${ }^{107}$ Since MAA payments now include the first thirty days' care in a county hospital, there probably will be cases in which "payments for care within three months prior to application" will include payments for the patient's first thirty days of treatment. Because federal approval of California's state plan providing for retroactive MAA payments apparently did not occur until August 16, 1963,108 however, it is probable that some counties anticipated having to finance their patients' first thirty days of care solely out of county funds until the effective date of section 4722.1 , July $23,1963,{ }^{109}$ and, consequently, acquired liens for reimbursement purposes from patients whose first thirty days of treatment occurred between February 1 and July 23. Release or reconveyance of these liens probably will be required in cases involving retroactive MAA payments covering the first thirty days of treatment, since federal approval of the state plan was subject to the established federal pohicy that no hens may be imposed on a patient's property because of MAA payments paid on his behalf. ${ }^{110}$

To the extent that the counties are compelled to release or reconvey liens as a result of the retroactive operation of state law in these three situations, the state must reckon with the Jessup doctrine invalidating releases or reconveyances of hens to persons ineligible for aid.

104 See text following note 96 supra.

105 Note 93 supra.

100 Car. Welfare \& Inst'Ns COde $\S 4731.5$, added by Cal. Stat. ch. 510, § 37.6, as amended, Cal. Stat. ch. 2166, §9 (1963).

107 See California State Department of Social Welfare Circular Letter No. 1376 (MC), at p. 4 (1963), and Circular Letter No. 1376-A. (MC), at p. 1 (1963).

108 Ibid.

109 Cal. Stat. ch. $2166, \S 11$ (1963) declares that the amendment to Car. Werfare \& INST'NS CODE $\$ 4722.1$ is an emergency measure which becomes effective immediately. The Governor signed the legislation on July $23,1963$.

11074 Stat. 989 (1960), 42 U.S.C. \$ 302 (a) (11) (E) (Supp. IV 1962) ; 76 Stat. 198 (1962), 42 U.S.C. $\S 1382$ (a) (15) (D) (Supp. IV 1962). 


\section{CONCLUSION}

Few would contend that any person who is financially able to pay his medical bill should not do so. Fewer would contend that payment of medical bills should be so burdensome as to pauperize a patient or his family.111

This proposition probably can be endorsed by both proponents and opponents of property liens which secure reimbursement for county hospital care. The state policy manifested by the 1963 amendments at least partially endorses the proposition by both reaffirming generally the authority of counties to take liens and tempering the authority with restrictions on enforcement of liens-particularly in cases where untimely foreclosure would deprive the patient or his relatives of a home.

A notable departure from the affirmance of county authority has been the substantial withdrawal of authority to impose liens on property belonging to recipients of categorical aid. The reasons for isolating categorical aid recipients for special treatment is unclear, especially since the approach apparently lias been to proliibit liens, but not to destroy the underlying liability for reimbursement.

Even if the policy supporting this approach is valid, the effective implementation of the policy may be hindered by the broad, soinetimes competing, sometimes overlapping language of the various 1963 welfare lien amendments. For instance, in some cases the amendments clearly apply to judgnent and execution liens; in other cases the coverage is not clear. Another example is the gap in the otherwise comprehensive prohibition of liens on the property of categorical aid recipients which is created by the unexplained omission of AFDC recipients from coverage for real property. The already difficult analysis of the effect of these amendments has been made even more complicated by the unresolved questions which linger with respect to the scope of county authority to impose hens prior to 1963.

The multitude of 1963 amendments amply demonstrates the legislature's concern regarding county lien policies. But this concern in many respects has not been translated into meaningful law with which counties can confidently and accuratcly comply.

A thorough study of California welfare lien policies, including a re-examination of the probable impact of the 1963 amendinents, seems imperative; and the embodiment of a clcar statement of these policies in a separate chapter of the Welfare and Institutions Code specifically relating to welfare liens would seein to be the desirable objective of such a study.

Paul M. Little

111 Greenfirdd, Property Liens For County Hospitax Care-A Collection Tool 3 (University of California Legislative Problems No. 8, 1961). 